\title{
IAMJ
}

INTERNATIONAL

AYURVEDIC

MEDICAL JOURNAL

\section{A PILOT STUDY ON THE EFFICACY OF JEERAKADI TAILA IN THE MANAGEMENT OF VANDHYATVA w.S.r. TO OVARIAN DYSFUNCTION}

\author{
Satish Jalihal $^{1}$, Shivakumar Kumbar², Susmitha B ${ }^{3}$ \\ ${ }^{1}$ M.S.(Ayu), Associate Professor, PG Dept. Prasuti Tantra \& Stree Roga, S.V.M. Ayurvedic Medical College, \\ Ilkal, Karnataka, India \\ ${ }^{2}$ M.S.(Ayu), Assistant Professor, PG Dept. Prasuti Tantra \& Stree Roga, S.J.G. Ayurvedic Medical College, \\ Koppal, Karnataka, India \\ ${ }^{3}$ M.S.(Ayu), Assistant Professor\& Consultant Obstetrician \& Gynaecologist, Vijayalkshmi Ayurvedalaya, \\ Dharmavaram, Andhra Pradesh, India
}

Email: $\underline{\text { satish.jalihal@gmail.com }}$

\section{https://doi.org/10.46607/iamjp04042020}

(Published online: May 2020)

Open Access

(C) International Ayurvedic Medical Journal, India 2020

Article Received: 20/04/2020 - Peer Reviewed: 07/05/2020 - Accepted for Publication: 10/05/2020

Check for updates

\begin{abstract}
Background: Procreation is a blessing that aids in transferring the genes from one generation to another and thus aids to evolution. As successful pregnancy is a multi-step chain of events, even if one of the events or conditions is not met in the right amount of time pregnancy may not happen or reach to birth. Infertility is a commonly increasing problem which any gynecologist has to face in their career. It affects the mental and physical health of women and disturbs her family as well as social life. Ovulatory factor is responsible for $30-40 \%$ cases of infertility. Ovulatory dysfunction encompasses anovulation or oligo-ovulation, decreased ovarian reserve, LPD, LUF. Acharya Sushruta has defined Vandhya as "Vandhya Nashtartavam Vidyat". According to Bhruhatraye, Shroni is the seat of vata. When Vata is vitiated by its aggravating factors or due to obstruction by Kapha it cannot govern its normal function and ovulatory dysfunction state persists. Objective: To assess the efficacy of an indigenous formula JEERAKADI TAILA in the management of Vandhyatva w.s.r.to Ovulatory dysfunction Methodology: 20 diagnosed patients of Ovulatory dysfunction were included and given Anubhuta Yoga Jeerakadi Taila 10-15 ml
\end{abstract}


BD with Ksheera and Sharkara as Anupana, before food for 3 consecutive menstrual cycles. Observation \& Results: On the basis of primary outcome: this product has shown satisfactory results in reducing cyst size, duration between cycles and induced ovulation in all patients and Secondary Outcome: - 6 patients conceived.

Key words: Jeerakadi Taila, Ovulatory Dysfunction, Vandhyatva, Infertility

\section{INTRODUCTION}

Procreation is a blessing that aids in transferring the genes from one generation to another and thus aids to evolution. Fertility is the capacity of a couple to reproduce. Vandhyatwa (Infertility) is a commonly increasing problem which any gynecologist has to face in their day-to-day practice. Infertility affects up to $15 \%$ of reproductive-aged couples worldwide. According to World Health Organization estimates the overall prevalence of primary infertility in India is between 3.9 to $16.8 \%$. In Indian states prevalence of infertility varies from state to state such as 3.7 per cent in Uttar Pradesh, Himachal Pradesh and Maharashtra, to 5 per cent in Andhra Pradesh, and 15 per cent in Kashmir and prevalence varies in same region across tribes and caste ${ }^{1}$. Conception depends on the fertility potential of both male and female partner. Female is directly responsible in about $30 \%$ of the cases. According to FIGO manual causes for female infertility are tubal factor $25-35 \%$, ovulatory dysfunction 30 $40 \%$, endometriosis $1-10 \%{ }^{2}$. Ovulatory dysfunction encompasses: Anovulation, decreased ovarian reserve, LPD, LUF. Acharya Sushruta has mentioned 4 essential components for conception: Rutu (Time), Kshetra (Uterus), Ambu (Nutritional Fluid), Beeja (Sperm \& Ovum) ${ }^{3}$. Here Beeja refers to ARTAVA (Ovum). "Vandhya Nashtartavam Vidyath"4.

The abnormal menstrual flow indicates scanty menstrual flow both in amount and duration. Artava Dushti leads to Beeja Naasha ${ }^{5}$ (Degeneration of Follicles). Anovulation or inability to produce a fertile ovum is an important reason among women facing infertility and still it is a growing problem due to change in lifestyle, faulty food habits, environment, stress provoking jobs etc.

\section{Materials and Methods}

Selection of patient: Patients were selected from outpatient dept of Prasutitantra And Stree Roga.

\section{Inclusion criteria}

- Age group between 20-35yrs

- Patients diagnosed as ovarian dysfunction with or without PCOS.

\section{Exclusion criteria}

- Systemic diseases like TB, DM, thyroid dysfunction, STDs, HIV, HBsAg

- Patients on OC Pills

- Premature ovarian failure

- Resistant ovarian syndrome

- Destruction of the ovaries by different radiation or oopherectomy

\section{Selection of drug}

Ingredients of Jeerakadi Taila are Krishna Tila (Sesamum indicum), Krishna Jeeraka (Cuminum cyminum), Shatapushpa (Peucedanum graveolens), Lashuna (Allium sativum), Vidarikanda (Pueraria tuberosa), Shatavari (Asparagus racemosus).

The drugs required for the study had procured from a GMP certified pharmacy under the supervision of Dept. of Dravya Guna, S.J.G.A.M. College and Research center Koppal and prepared in Rasa Baishjya Kalpana dept according to classical method.

Drugs for Jeerakadi Taila were selected on the basis of individual scientifically proven effect on ovulation.

\section{Posology}

- Duration of treatment: 3 consecutive menstrual cycles.

- Dose: 10-15 ml BD with Ksheera (Milk) and Sharkara (Sugar) as Anupana (Vehicle), before food.

- Follow up:

$\checkmark$ During treatment

Patients were called on day 3 of every cycle for baseline scan and day 10th onwards serial follicular scan till ovulation. This was repeated for 3 cycles. 
After treatment

Same was followed for 1 cycle.

\section{Diagnostic Criteria:}

- Irregular menstruation

- Follicular study- H/O last 2 anovulatory cycles

- Subjective parameter- regular/irregular menses

- Objective parameter- follicular study, duration between cycles.

Assessment Criteria:

\section{Subjective parameters}

- Regular/Irregular menses.

$>$ Objective parameters

- Follicular study

- Duration between cycles.

\section{Investigations}

TVS was carried out from day 9th of menstrual cycle up to ovulation. In all the patients, TVS was carried out for 3 consecutive cycles for final diagnosis.

- Hormonal Assay \& Ovarian reserve- AMH

- Blood investigation- CBC, HIV, HBsAg, VDRL

\section{Overall effect of treatment}

The overall effect was graded into four types:

Conceived: The patient's husband otherwise normal was conceived after the treatment

Complete remission: Ovulation occurred

Improved: Ovulation not occurred but only improvement in the size of follicles, i.e. $12-18 \mathrm{~mm}$

Unchanged: No change in the growth of the follicle.

\section{Observation}

Table 1: Total 20patients were registered in the present study; all the patients completed the treatment.

\begin{tabular}{|l|l|l|}
\hline Age & $\mathrm{N}=20$ & $\%$ \\
\hline $20-25$ & 07 & 35 \\
\hline $26-30$ & 08 & 40 \\
\hline $31-35$ & 05 & 25 \\
\hline
\end{tabular}

Table 2: Demography data based on chronicity of Infertility

Chronicity of infertility

Less than 5 yrs

\begin{tabular}{|l|l|}
\hline $\mathrm{N}=20$ & $\%$ \\
\hline 07 & 35 \\
\hline 13 & 65 \\
\hline
\end{tabular}

More than $5 \mathrm{yrs}$

65

Table 3: Demography data based on inclusion of PCOS cases

\begin{tabular}{|l|l|l|}
\hline & $\mathrm{N}=20$ & $\%$ \\
\hline With PCOS & 07 & 35 \\
\hline Without PCOS & 13 & 65 \\
\hline
\end{tabular}

Table 4: Demography data based on Menstrual History

\begin{tabular}{|l|l|l|}
\hline Interval $\mathrm{b} / \mathrm{w}$ cycle & $\mathrm{N}=20$ & $\%$ \\
\hline $35-40$ days & 10 & 50 \\
\hline $46-90$ days & 6 & 30 \\
\hline 90 days & 4 & 20 \\
\hline
\end{tabular}

\section{Results:}

Before treatment all the patients (100\%) were having no dominant follicle (NDF). After treatment all the patients ovulated $(70 \%)$ where $\mathrm{N}=14$.
Totally 6 patients $(30 \%)$ were conceived.

After treatment 14 patients $(70 \%)(\mathrm{N}=14)$ regained normal cycle length i.e. 28-34days. 
Table 5: Results showing changes in Follicular growth

\begin{tabular}{|l|l|l|l|l|}
\hline Follicular study & Before treatment & After treatment \\
\hline & $\mathrm{N}=20$ & $\%$ & $\mathrm{~N}=14$ & $\%$ \\
\hline NDF & 20 & 100 & 0 & 0 \\
\hline $0-12 \mathrm{~mm}$ & 0 & 0 & 0 & 0 \\
\hline $13-17 \mathrm{~mm}$ & 0 & 0 & 0 & 0 \\
\hline$>18 \mathrm{~mm}$ & 0 & 0 & 14 & 100 \\
\hline
\end{tabular}

Table 6: Results showing changes in Menstrual Cycle length

\begin{tabular}{|l|l|l|l|l|}
\hline Cycle length & Before treatment & After treatment \\
\hline & $\mathrm{N}=20$ & $\%$ & $\mathrm{~N}=14$ & $\%$ \\
\hline 28-34 days & 0 & 0 & 14 & 100 \\
\hline 35-40 days & 10 & 50 & 0 & 0 \\
\hline 46-90 days & 6 & 30 & 0 & 0 \\
\hline$>90$ days & 4 & 20 & 0 & 0 \\
\hline
\end{tabular}

Table 7: Results showing number of patients conceived with treatment

\begin{tabular}{|l|l|l|}
\hline & $\mathrm{N}=20$ & $\%$ \\
\hline No of patients conceived & 6 & 30
\end{tabular}

On the basis of primary outcome: This product has shown satisfactory results in reducing cyst size, duration between cycles and induced ovulation in all patients.

Mode of action: $50 \%$ of the drugs having Madhura Rasa which does Vata Shaman and Rasa Dhatu Vrudhi, Tikta Rasa has Srotoshodhaka (Cleansing) and Kapha Nissaraka Karma (Removal of moisture). 50\% of the drugs having Ushna Veerya helped for Vata Shaman and Artava Janana (Ovulation). As most of the drugs having Artava Janana, Garbhashaya Shodhana (Cleansing of Uterus), Shukrala (Steroidogenesis), Vrushya Karma (Aphrodesiac) helped for Kshetra and Beeja Shuddhi.

\section{CONCLUSION}

Infertility is a burning issue nowadays, that too with advanced technologies made natural conception as a dream. We are witnessing rapid increase in the rate of Assisted Reproductive Centres in our country, that too they reached almost district places. To promote natural conception and to cut off the cost of treatment, Jeerakadi Taila is an alternative choice. This pilot study showed $100 \%$ results in Ovulatory dysfunctions by developing healthy Graaffian Follicle. 6 patients conceived during study period. So, this study can be tried on large samples to draw more data on the efficacy using standard research protocols.

\section{REFERENCES}

1. WebSource:

https://www.nhp.gov.in/disease/reproductive-

system/infertility

2. Dutta DC. In: Konar H, editor. Textbook of Gynaecology. 6th ed.

3. Sushruta, Sushruta Samhita, Sharira Sthana, 2/33. Reprint edition. Varanasi:Surabharati Prakashana; 2003.

4. Agnivesha, Charaka, Dridhabala, Charaka Samhita, Sutra Sthana, Vatakalakaliya Adhyaya, 12/8, Jadavaji Trikamji Acharya editor. 4th ed.Varanasi: Chaukhambha Sanskrit Sansthan

5. Vagbhata, Ashtanga Hridaya, Uttar Tantra, Guhyaroga Pratishedha, 34/23, Bhishgacharya Harishastri Paradkara Vaidya editor. Reprint 9th ed. Varanasi: Chaukhambha Orientalia \& Kashyapa, Kashyapa Samhita, Khila Sthana, 9/11, edited by PanditaHemaraja Sharama and Sri Satyapala Bhisagacharya. Reprint edition.Varanasi: Chaukhambha Sanskrit Sansthan; 2009.

6. Bhavamishra. Bahvaprakash Nighantu. Edited by Dr. G.S. Pandey and Commentary by Dr. Krishnachandra 
Chunekar. Chaukhambha Bharati Academy, Varanasi (India). 10th Edition, 1995.

7. Bhavamishra. Bhavaprakash. (Text, English translation, Notes, Appendices, and Index) by Prof. K.R. Srikantha Murthy Chukhambha Krishnadas Academy, Varanasi. Edition 2004.

8. Dwivedi Vishwanatha. Aushadhi Vijnana Shastra. (Ayurvedic Pharmacology). Sri Bhaidhyanath Ayurveda Bhawan (P) Ltd. Nagapur (India). 3 rd Edition 1986.

9. Sharma. P.V. Classical uses of Medicinal Plants. Chaukhambha. Vishvabharati. Varanasi, India. Reprint year 2004.

10. Sharma. P.V. Dravyaguna Vignyana. Chaukhambha Amarabharathi Prakashana, Varanasi. UP 1998.

\section{Source of Support: Nil \\ Conflict of Interest: None Declared \\ How to cite this URL: Satish Jalihal et al: A Pilot Study On The Efficacy Of Jeerakadi Taila In The Management Of Vandhyatva W.S.R. To Ovarian Dysfunction. International Ayurvedic Medical Journal \{online\} 2020 \{cited May, 2020\} Available from: http://www.iamj.in/posts/images/upload/2324_2328.pdf}

